\title{
Pembelajaran Menulis Karya Tulis Ilmiah dengan Metode Discovery di Perguruan Tinggi
}

\author{
Marya Ulfa \\ Faculty of Language and Culture, Universitas 17 Agustus 1945 Semarang \\ Email: maryau700@gmail.com
}

\begin{abstract}
This research is entitled "Learning to Write Scientific Papers with the Discovery Method in Higher Education". The problem in this research is how to learn scientific writing with the discovery method in universities? The purpose of this research is to describe the learning of scientific writing with the discovery method in universities. The method used in this research is descriptive qualitative. Based on the results of the study, the discovery method has not been widely applied by lecturers in learning scientific writing. The obstacles are 1) lecturers still use the assignment method and examples, 2) lecturers still have difficulty in compiling learning tools using the discovery method, and 3) lecturers only provide scientific writing material due to a systematic misunderstanding between general and environmental rules. Therefore, scientific writing material needs to be given to students based on the discovery method. The selection of the right learning method is very influential on the success of students in scientific writing. The facts obtained indicate the need for appropriate learning methods.
\end{abstract}

Keywords: Writing, Scientific Writing, and Discovery Method.

\section{RINGKASAN}

Penelitian ini berjudul "Pembelajaran Menulis Karya Tulis Ilmiah dengan Metode Discovery di Perguruan Tinggi”. Permasalahan dalam penelitian ini yaitu bagaimana pembelajaran karya tulis ilmiah dengan metode discovery di perguruan tinggi? Tujuan dalam penelitian ini adalah mendekripsikan pembelajaran karya tulis ilmiah dengan metode discovery di perguruan tinggi. Metode yang digunakan dalam penelitian yaitu deskriptif kualitatif. Berdasarkan hasil penelitian, metode discovery belum banyak diterapkan dosen dalam pembelajaran karya tulis ilmiah. Ada pun kendalanya adalah 1) dosen masih menggunakan metode penugasan dan contoh, 2) dosen masih mengalami kesulitan dalam menyusun perangkat pembelajaran dengan metode discovery, dan 3) dosen hanya memberikan materi karya tulis ilmiah disebabkan oleh ketidakfahaman sistematika antara kaidah secara umum dan selingkung. Oleh karena itu, materi karya tulis ilmiah perlu diberikan kepada mahasiswa dengan berbasis metode discovery. Pemilihan metode pembelajaran yang tepat sangat berpengaruh terhadap keberhasilan mahasiswa dalam menulis karya tulis ilmiah. Fakta yang diperoleh menunjukkan adanya kebutuhan metode pembelajaran yang tepat.

Kata Kunci: Menulis, Karya Tulis Ilmiah, dan Metode Discovery. 


\section{Pendahuluan}

Berdasarkan wawancara yang dilakukan terhadap beberapa dosen dan mahasiswa pada perkuliahan karya tulis ilmiah di Universitas 17 Agustus 1945 Semarang pada tahun 2020, diperoleh keterangan bahwa pembelajaran karya tulis ilmiah hampir tidak diberikan secara intensif. Karya tulis ilmiah hanya sebagai pengetahuan yang diberikan kepada mahasiswa tanpa adanya pendalaman dan tindak lanjut untuk memproduksinya. Terdapat juga salah tafsir mengenai kaidah secara umum dan selingkung.

Sistematika penulisan karya tulis ilmiah antara kaidah secara umum dan selingkung dianggap sama. Butuh metode dan cara yang tepat untuk memberikan pemahaman mahasiswa agar tercipta keselarasan. Dengan demikian, diperlukan perangkat pembelajaran yang tepat.

Selanjutnya, permasalahan dalam penelitian adalah bagaimana pembelajaran karya tulis ilmiah dengan metode discovery di perguruan tinggi. Tujuan dalam penelitian ini yaitu mendekripsikan pembelajaran menulis cerita bergambar dengan metode discovery di perguruan tinggi. Melalui proses tersebut, diharapkan pembelajaran karya tulis ilmiah dengan metode discovery di perguruan tinggi dapat optimal.

\section{Landasan Teori}

\subsection{Karya Tulis Ilmiah}

Dwiloka dan Riana (2005:1-2) Karya ilmiah atau tulisan ilmiah adalah karya seorang ilmuwan (yang berupa hasil pengembangan) yang ingin mengembangkan ilmu pengetahuan, teknologi, dan seni yang diperolehnya melalui kepustakaan,kumpulan pengalaman, penelitian, dan pengetahuan oranglain sebelumnya.

Menurut Yamilah dan Samsoerizal (1994 : 90) memaparkan bahwa ragam karya ilmiah terdiri atas beberapa jenis berdasarkan fungsinya. Menurut pengelompokan itu, dikenal ragam karya ilmiah seperti ; makalah, skripsi, tesis, dan disertasi. 
Menurut Sikumbang (1981), sekurang-kurangnya ada enam manfaat yang diperoleh dari kegiatan tersebut.

a. Penulis dapat terlatih mengembangkan keterampilan membaca yang efektif karena sebelum menulis karya ilmiah, pasti membaca dahulu kepustakaan yang ada relevansinya dengan topik yang hendak dibahas.

b. Penulis dapat terlatih menggabungkan hasil bacaan dari berbagai sumber, mengambil sarinya, dan mengembangkannya ke tingkat pemikiran yang lebih matang.

c. Penulis dapat berkenalan dengan kegiatan perpustakaan seperti mencari bahan bacaan dalam katalog pengarang atau katalog judul buku.

d. Penulis dapat meningkatkan keterampilan dalam mengorganisasi dan menyajikan data dan fakta secara jelas dan sistematis.

e. Penulis dapat memperoleh kepuasan intelektual.

f. Penulis turut memperluas cakrawala ilmu pengetahuan masyarakat.

Salah satu dasar penggolongan karangan disebut oleh jones (1960), yang membagi karangan ilmiah dan karangan non-ilmiah, berdasarkan fakta yang disajikan dalam karangan itu, yaitu fakta umum dan fakta pribadi (Haryanto dkk, 2000:7) Penggolongan bisa pula dilakukan berdasarkan metodologi penulisanya, menjadi karangan ilmiah dan karangan tidak ilmiah. Bila karangan menyajikan fakta umum maupun pribadi, namun disajikan tidak dengan metoda yang baik dan benar maka disebut karangan yang tidak ilmiah (Haryanto dkk, 2000:7)

Berdasarkan pada uraian di atas, dapat disimpulkan bahwa karya tulis ilmiah adalah suatu karangan atau tulisan yang diperoleh sesuai dengan sifat keilmuannya dan didasari oleh hasil pengamatan, peninjauan, penelitian dalam bidang tertentu, disusun menurut metode tertentu dengan sistematika penulisan yang bersantun bahasa dan isinya dapat dipertanggungjawabkan kebenarannya/ keilmiahannya.

\subsection{Hakikat Metode Discovery}

Ditinjau dari kata discover berarti menemukan, sedangkan discovery adalah penemuan (Echol dan Sadili 1996:185). Berkaitan dengan pendidikan, 
Hamalik (1994:90-91) menyatakan bahwa discovery merupakan proses pembelajaran yang menitikberatkan pada mental intelektual para peserta didik dalam memecahkan berbagai persoalan yang dihadapi, sehingga menemukan suatu konsep atau generalisasi yang dapat diterapkan di lapangan.

Dengan kata lain, kemampuan mental intelektual merupakan faktor penentuan terhadap keberhasilan dalam menyelesaikan setiap tantangan yang dihadapi, termasuk persoalan belajar. Berkaitan dengan pendapat diatas, metode pembelajaran yang dikembangkan Bruner (dalam Djamarah 1996:22) lebih menitikberatkan pada kemampuan peserta didik dalam menemukan sesuatu melalui proses inquiry (penelitian) secara terstruktur dan terorganisir dengan baik.

Hal tersebut sejalan dengan pendapat Siregar (1985:76-77) bahwa discovery by learning adalah proses pembelajaran untuk menemukan sesuatu yang baru dalam kegiatan belajar-mengajar. Proses belajar dapat menemukan sesuatu apabila pendidik menyusun terlebih dahulu beragam materi yang akan disampaikan, selanjutnya mereka dapat melakukan proses untuk menemukan sendiri berbagai hal penting terkait dengan kesulitan dalam pembelajaran.

Pada tataran aplikasi, discovery disajikan dalan bentuk yang cukup sederhana, fleksibel, dan mandiri.Kendati demikian, masih diperlukan adanya pengkajian-pengkajian secara empiris dan praktis yang menuntut perserta didik lebih peka dalam mengoptimalkan kecerdasan intelektual dengan matang, tanpa banyak bergantung pada arahan pendidik.

Hal tersebut berkaitan dengan pandangan Ilahi (2012:33) bahwa discovery merupakan salah satu metode yang memungkinkan para peserta didik terlibat langsung dalam kegiatan belajar-mengajar, sehingga mampu menggunakan proses mental untuk menemukan suatu konsep atau teori yang sedang dipelajari. Dengan kata lain, landasan pemikiran yang mendasai pendekatan belajar-mengajar ini bisa lebih mudah dihafal dan diingat, serta mudah ditransformasikan dalam menghadapi kompleksitas permasalahan yang beragam. 
Berdasarkan berberapa pengertian yang sudah dijelaskan, aplikasi metode pembelajaran yang kreatif dan inovatif dari discovery sangat berkaitan dengan realitas kehidupan yang empiris. Mengingat pembelajaran yang dilaksanakan dalam kelas sangat relevan dengan perkembangan zaman, terutama kemandirian peserta didik dalam menghadapi suatu persoalan kehidupan yang menuntut pemecahan secara holistik. Dengan demikian, tidak heran bila alternatif metode pembelajaran yang dianggap relevan dengan realitas kehidupan adalah bagaiamana perserta didik mampu diajak dan diberi motivasi untuk berpikir inovatif dalam menemukan sesuatau yang baru. Metode pembelajaran ini pada gilirannya akan mampu merangsang mahasiswa dalam menganalisis suatu persoalan yang sedang terjadi. Selain itu, aplikasi discovery juga menekan proses pengembangan diri (self development) yang menuntut mereka bisa mengolah pikiran dan mengoptimalkan potensi.

Pada aplikasi tersebut, terdapat implikasi yang mendasari discovery learning sejalan dengan pernyataan Soemanto (2006:228), yaitu a) potensi intelektual para peserta didik akan semakin meningkat, b) peserta didik akan belajar mengorganisasi dan menghadapi problem dengan metode pencarian masalah dengan memecahkan masalah sendiri yang sesuai dengan kapasitas mereka sebagai pembelajaran, dan c) discovery mengarah pada self reward. Dengan demikian, berbagai implikasipembelajaran discovery sangat efektif dan efisien dalam mendayagunakan skill peserta didik untuk belajar memahami arti pendidikan yang sebenarnya.

Pada sistem pembelajaran discovery, seorang pendidik tidak langsung menyajikan bahan pelajaran, akan tetapi peserta didik diberi peluang untunk menemukan sendiri suatu persoalan dengan menggunakan pendekatan problem solving.Selain itu, Ahmad dan Prasetya (2005:22) mengemukakan secara garis besar bahwa prosedur pembelajaran berdasarkan penemuan (discovery based learning) adalah 1) simulation, 2) problem statement,data collection, 4) data processing, 5) verification, dan 6) generalization. 
Kegiatan discovery dapat dilakukan dengan melalui berbagai cara sesuai yang ditawarkan Ibrahim dan Syaodih (2003:38), yaitu a) berdiskusi, b) bertanya, c) observation, d) experiment,e) menstimulasi, f) inquiry approach, dan g) memecahkan masalah.

\section{Metode Penelitian}

Metode yang digunakan dalam penelitian yaitu deskriptif kualitatif. Data-data diperoleh melalui wawancara, observasi, dan angket terhadap dosen dan mahasiswa di Universitas 17 Agustus 1945 Semarang, Universitas AKI Semarang, dan Universitas Karya Husada Semarang. Selanjutnya, dilakukan triangulasi terhadap data-data hasil penelitian yang telah diperoleh. Dengan demikian, data hasil penelitian yang diperoleh dan dideskripsikan akurat/valid.

\section{Hasil dan Pembahasan}

\subsection{Hasil Wawancara}

Tahap ini dilaksanakan pada bulan April dan Mei di Universitas 17 Agustus 1945 Semarang, Universitas AKI Semarang, dan Universitas Karya Husada Semarang. Berdasarkan wawancara kepada dosen dan mahasiswa diperoleh data sebagai berikut.

Analisis kebutuhan mahasiswa dalam pembelajaran karya tulis ilmiah berdasarkan hasil wawancara dengan mahasiswa Universitas 17 Agustus 1945 Semarang. Responden berjumlah 24 berpendapat bahwa karya tulis ilmiah adalah karangan ilmu pengetahuan yang menyajikan fakta dan ditulis menurut metodologi penulisan yang baik dan benar.

Responden berjumlah 26 hanya menjelaskan makna karya tulis ilmiah. Pernah sebelum mengikuti kuliah (14), tidak mengisi (1), belum pernah (35). Menulis karya tulis ilmiah memerlukan pemikiran lebih mendalam. Media dan metode pendukung sangat diperlukan.

Dengan adanya media dan metode pendukung akan mempermudah dalam membuat karya tulis ilmiah secara sistematis 
Responden menjawab tidak tahu (38), tidak mengisi (5), (7) menjawab Media dan metode yang digunakan untuk membuat karya tulis ilmiah tepat dan tidak membosankan. Tidak menjawab (6), belum pernah (44), Tidak pernah (49) pernah (1) pada mata kuliah metodologi penelitian.

Metode yang menuntut siswa agar lebih aktif dalam pembelajaran dan dapat mencari permasalahnnya sendiri, pembelajaran yang mengedepankan siswa mencari permasalahan sendiri. Pembelajaran yang berbasis masalah, ditekankan pada ditemukannya konsep sendiri, Tidak pernah (8), tidak menjawab (2), pernah (40) pada mata kuliah metode penelitian bahasa dan sastra. Pembelajaran ini dapat membantu peserta didik lebih mandiri, sangat menantang dan menyenangkan, dalam pembelajaran lebih bervariasi, pembelajaran lebih hidup, mahasiswa dapat menemukan sesuatu yang baru.

Sementara itu, hasil wawancara dari Universitas AKI Semarang diperoleh terhadap responden menjawab pernah (14), tidak pernah (1), pernah untuk mata kuliah estetik (4), pernah untuk mata kuliah metodologi penelitian (17), media Pembelajaran (2), tidak menjawab (2). Responden tidak pernah (7), tidak menjawab (2), pernah ketika menulis ide kreatif di android masingmasing (12).

Responden menjawab perlu, karena untuk menunjang dan mempermudah dalam membuat karya tulis ilmiah, pembelajaran tidak monoton, mempermudah menemukan inspirasi dalam membuat karya tulis ilmiah. Tidak tahu (15), tidak menjawab (4), suatu aplikasi dalam komputer yang digunakan untuk membuat media pembelajaran. Belum pernah (18), tidak menjawab (3).

Berbeda dengan itu, hasil wawancara yang dilakukan di Universitas Karya Husada terhadap responden adalah karya tulis ilmiah adalah menarik, kreatif, dan ilmiah yang di dalamnya terdapat kaidah-kaidah dalam sistematika. Responden pernah mendapatkan materi karya tulis ilmiah. Mata kuliah metode penelitian. Responden sangat sulit memaparkan latar belakang dalam penelitian karena belum ada ide jadi masih sulit dituangkan dalam bentuk tulisan. 
Responden memerlukan media yang tepat untuk menulis, agar karya tulis ilmiah mampu diciptakan dalam bentuk tulisan dan ada tempat untuk mencurahkan inspirasi dalam melakukan penelitian. Pembelajaran discovery adalah pembelajaran yang bermakana, karena mampu menemukan sendiri. Responden pernah menggunakan media discovery pada mata kuliah yang lain. Pembelajaran dengan metode discovery sangat menyenangkan karena pembelajarannya inovatif dan kreatif, sehingga tidak bosan dalam pembelajaran.

\subsection{Hasil Observasi}

Tahap ini dilaksanakan pada bulan April dan Mei di Universitas 17 Agustus 1945 Semarang, Universitas AKI Semarang, dan Universitas Karya Husada Semarang. Berdasarkan observasi yang diperoleh dari masing-masing perguruan tinggi diperoleh data bahwa 1) mahasiswa belum memahami perbedaan antara kaidah secara umum dan kaidah selingkung, 2) karya tulis ilmiah tidak diberikan secara intensif, 3) pembelajaran karya tulis ilmiah disampaikan dengan metode penugasan dan contoh yang menjadikan mahasiswa cenderung jenuh dan tidak memahami secara mendalam hakikat karya tulis ilmiah, dan 4) pembelajaran yang tidak student centered melainkan teacher centered sehingga pembelajaran banyak berorientasi pada dosen dan mahasiswa hanya menerima materi tanpa melakukan penemuan secara langsung dan mandiri.

\subsection{Hasil Angket}

Berdasarkan angket yang diberikan kepada dosen dan mahasiswa di Universitas 17 Agustus 1945 Semarang diperoleh data bahwa hasil angket dari 12 pertanyaan yang diajukan kepada 50 mahasiswa Universitas 17 Agustus 1945 Semarang. Tanggapan responden menunjukkan bahwa sebagian besar responden memberikan tanggapan terhadap pertanyaan yang diajukan. Rata-rata indeks skor jawaban berada pada rentang indeks skor tinggi.

Berdasarkan data tersebut pertanyaan pertama mengenai pengetahuan tentang karya tulis ilmiah 6 responden menjawab ya, 1 menjawab tidak, 0 
menjawab pernah, 1 menjawab tidak pernah, 11 menjawab perlu, dan 1 menjawab tidak perlu. Hal ini menunjukkan bahwa karya tulis ilmiah perlu diajarkan untuk mahasiswa. Pertanyaan kedua mengenai materi karya tulis ilmiah, 3 responden menjawab ya, 16 menjawab tidak, 11 menjawab pernah, 18 menjawab tidak pernah, 0 menjawab perlu, dan 0 menjawab tidak perlu. Hal ini menunjukkan bahwa materi kurang diajarkan pada mahasiswa.

Pertanyaan ketiga mengenai mata kuliah tentang karya tulis ilmiah, 2 responden menjawab ya, 14 menjawab tidak, 0 menjawab pernah, 7 menjawab tidak pernah, 0 menjawab perlu, dan 0 menjawab tidak perlu. Hal ini menunjukkan bahwa tidak ada mata kuliah tentang karya tulis ilmiah. Pertanyaan keempat mengenai kesulitan dalam menulis karya tulis ilmiah, 16 responden menjawab ya, 5 menjawab tidak, 19 menjawab pernah, 6 menjawab tidak pernah, 0 menjawab perlu, dan 0 menjawab tidak perlu. Hal ini menunjukkan bahwa mahasiswa pernah mengalami kesulitan dalam menulis karya tulis ilmiah.

Pertanyaan kelima mengenai keperluan media untuk menulis karya tulis ilmiah, 19 responden menjawab ya, 0 menjawab tidak, 0 menjawab pernah, 1 menjawab tidak pernah, 29 menjawab perlu, dan 0 menjawab tidak perlu. Hal ini menunjukkan bahwa mahasiswa memerlukan media untuk menulis karya tulis ilmiah. Pertanyaan keenam mengenai metode pembelajaran discovery, 15 responden menjawab ya, 6 menjawab tidak, 4 menjawab pernah, 0 menjawab tidak pernah, 0 menjawab perlu, dan 0 menjawab tidak perlu. Hal ini menunjukkan bahwa mahasiswa mengetahui metode pembelajaran discovery.

Pertanyaan ketujuh mengenai materi menggunakan metode discovery, 7 responden menjawab ya, 8 menjawab tidak, 31 menjawab pernah, 1 menjawab tidak pernah, 0 menjawab perlu, dan 0 menjawab tidak perlu. Hal ini menunjukkan bahwa metode discovery pernah diajarkan pada mahasiswa. Pertanyaan kedelapan mengenai hasil pembelajaran menggunakan metode discovery. 9 responden menjawab ya, 5 menjawab tidak, 19 menjawab pernah, 4 menjawab tidak pernah, 0 menjawab perlu, dan 0 menjawab tidak 
perlu. Hal ini menunjukkan bahwa mahasiswa pernah berhasil dengan metode discovery.

Berdasarkan data tersebut menunjukkan bahwa 83 responden menjawab ya, 105 responden menjawab tidak, 81 responden menjawab pernah, 133 responden menjawab tidak pernah, 40 responden menjawab perlu, dan 1 responden menjawab tidak perlu. Berdasarkan data tersebut jumlah tertinggi adalah 133 yaitu responden tidak pernah menggunakan media pembelajaran menulis cerita bergambar dengan metode discovery.

Sementara itu, berdasarkan angket yang diberikan kepada dosen dan mahasiswa di Universitas AKI Semarang diperoleh data bahwa hasil angket dari 12 pertanyaan yang diajukan kepada 50 mahasiswa Universitas AKI Semarang. Tanggapan responden menunjukkan bahwa sebagian besar responden memberikan tanggapan terhadap pertanyaan yang diajukan. Ratarata indeks skor jawaban berada pada rentang indeks skor tinggi.

Berdasarkan data tersebut pertanyaan pertama mengenai pengetahuan tentang karya tulis ilmiah 24 responden menjawab ya, 0 menjawab tidak, 9 menjawab pernah, 0 menjawab tidak pernah, 3 menjawab perlu, dan 0 menjawab tidak perlu. Hal ini menunjukkan bahwa karya tulis ilmiah perlu diajarkan untuk mahasiswa. Pertanyaan kedua mengenai materi karya tulis ilmiah, 0 responden menjawab ya, 3 menjawab tidak, 45 menjawab pernah, 3 menjawab tidak pernah, 0 menjawab perlu, dan 0 menjawab tidak perlu. Hal ini menunjukkan bahwa materi karya tulis ilmiah pernah diajarkan pada mahasiswa.

Pertanyaan ketiga mengenai mata kuliah tentang karya tulis ilmiah, 12 responden menjawab ya, 0 menjawab tidak, 27 menjawab pernah, 3 menjawab tidak pernah, 0 menjawab perlu, dan 0 menjawab tidak perlu. Hal ini menunjukkan bahwa pernah mendapat karya tulis ilmiah pada mata kuliah tertentu. Pertanyaan keempat mengenai kesulitan dalam menulis karya tulis ilmiah, 0 responden menjawab ya, 18 menjawab tidak, 33 menjawab pernah, 6 menjawab tidak pernah, 0 menjawab perlu, dan 0 menjawab tidak perlu. Hal 
ini menunjukkan bahwa mahasiswa pernah mengalami kesulitan dalam menulis karya tulis ilmiah.

Pertanyaan kelima mengenai keperluan media untuk menulis karya tulis ilmiah, 9 responden menjawab ya, 0 menjawab tidak, 0 menjawab pernah, 0 menjawab tidak pernah, 45 menjawab perlu, dan 0 menjawab tidak perlu. Hal ini menunjukkan bahwa mahasiswa memerlukan media untuk menulis karya tulis ilmiah. Pertanyaan keenam mengenai metode pembelajaran discovery, 0 responden menjawab ya, 39 menjawab tidak, 0 menjawab pernah, 6 menjawab tidak pernah, 0 menjawab perlu, dan 0 menjawab tidak perlu. Hal ini menunjukkan bahwa mahasiswa tidak mengetahui metode pembelajaran discovery.

Pertanyaan ketujuh mengenai materi menggunakan metode discovery, 0 responden menjawab ya, 36 menjawab tidak, 0 menjawab pernah, 15 menjawab tidak pernah, 0 menjawab perlu, dan 0 menjawab tidak perlu. Hal ini menunjukkan bahwa metode discovery tidak diajarkan pada mahasiswa. Pertanyaan kedelapan mengenai hasil pembelajaran menggunakan metode discovery. 0 responden menjawab ya, 30 menjawab tidak, 0 menjawab pernah, 6 menjawab tidak pernah, 6 menjawab perlu, dan 0 menjawab tidak perlu. Hal ini menunjukkan bahwa mahasiswa tidak pernah berhasil dengan metode discovery.

Berdasarkan data tersebut menunjukkan bahwa 52 responden menjawab ya, 176 responden menjawab tidak, 96 responden menjawab pernah, 80 responden menjawab tidak pernah, 56 responden menjawab perlu, dan 0 responden menjawab tidak perlu. Berdasarkan data tersebut jumlah tertinggi adalah 176 yaitu responden tidak menggunakan media pembelajaran menulis cerita bergambar.

Berbeda dengan hal tersebut, berdasarkan angket yang diberikan kepada dosen dan mahasiswa di Universitas Karya Husada Semarang diperoleh data hasil angket dari 12 pertanyaan yang diajukan kepada 50 mahasiswa Universitas Karya Husada Semarang. Tanggapan responden menunjukkan bahwa sebagian besar responden memberikan tanggapan 
terhadap pertanyaan yang diajukan. Rata-rata indeks skor jawaban berada pada rentang indeks skor tinggi.

Berdasarkan data tersebut pertanyaan pertama mengenai pengetahuan tentang karya tulis ilmiah 3 responden menjawab ya, 0 menjawab tidak, 0 menjawab pernah, 0 menjawab tidak pernah, 1 menjawab perlu, dan 0 menjawab tidak perlu. Hal ini menunjukkan bahwa karya tulis ilmiah perlu diajarkan untuk mahasiswa. Pertanyaan kedua mengenai materi karya tulis ilmiah, 1 responden menjawab ya, 2 menjawab tidak, 21 menjawab pernah, 0 menjawab tidak pernah, 0 menjawab perlu, dan 0 menjawab tidak perlu. Hal ini menunjukkan bahwa materi tidak pernah diajarkan pada mahasiswa.

Pertanyaan ketiga mengenai mata kuliah tentang karya tulis ilmiah, 2 responden menjawab ya, 0 menjawab tidak, 19 menjawab pernah, 0 menjawab tidak pernah, 0 menjawab perlu, dan 0 menjawab tidak perlu. Hal ini menunjukkan bahwa tidak ada mata kuliah tentang karya tulis ilmiah. Pertanyaan keempat mengenai kesulitan dalam menulis karya tulis ilmiah, 0 responden menjawab ya, 1 menjawab tidak, 23 menjawab pernah, 0 menjawab tidak pernah, 0 menjawab perlu, dan 0 menjawab tidak perlu. Hal ini menunjukkan bahwa mahasiswa pernah mengalami kesulitan dalam menulis karya tulis ilmiah.

Pertanyaan kelima mengenai keperluan media untuk menulis karya tulis ilmiah, 0 responden menjawab ya, 0 menjawab tidak, 1 menjawab pernah, 0 menjawab tidak pernah, 22 menjawab perlu, dan 0 menjawab tidak perlu. Hal ini menunjukkan bahwa mahasiswa memerlukan media untuk menulis karya tulis ilmiah. Pertanyaan keenam mengenai metode pembelajaran discovery, 4 responden menjawab ya, 2 menjawab tidak, 2 menjawab pernah, 0 menjawab tidak pernah, 0 menjawab perlu, dan 0 menjawab tidak perlu. Hal ini menunjukkan bahwa mahasiswa mengetahui metode pembelajaran discovery.

Pertanyaan ketujuh mengenai materi menggunakan metode discovery, 0 responden menjawab ya, 0 menjawab tidak, 22 menjawab pernah, 0 menjawab tidak pernah, 0 menjawab perlu, dan 0 menjawab tidak perlu. Hal ini menunjukkan bahwa metode discovery pernah diajarkan pada mahasiswa. 
Pertanyaan kedelapan mengenai hasil pembelajaran menggunakan metode discovery. 7 responden menjawab ya, 0 menjawab tidak, 8 menjawab pernah, 0 menjawab tidak pernah, 0 menjawab perlu, dan 0 menjawab tidak perlu. Hal ini menunjukkan bahwa mahasiswa pernah berhasil dengan metode discovery.

Berdasarkan data tersebut menunjukkan bahwa 22 responden menjawab ya, 35 responden menjawab tidak, 101 responden menjawab pernah, 47 responden menjawab tidak pernah, 23 responden menjawab perlu, dan 0 responden menjawab tidak perlu. Berdasarkan data tersebut jumlah tertinggi adalah 101 yaitu responden pernah menggunakan media pembelajaran menulis cerita bergambar dengan metode discovery, tetapi masih dibutuhkan hal yang beda, penyempurnaan, dan lebih menarik lagi.

\section{Simpulan}

Berdasarkan hasil penelitian, metode discovery belum banyak diterapkan oleh para dosen dalam pembelajaran karya tulis ilmiah. Ada pun kendalanya adalah 1) dosen masih menggunakan metode penugasan dan contoh, 2) dosen masih mengalami kesulitan dalam menyusun perangkat pembelajaran dengan metode discovery, dan 3) dosen hanya memberikan materi karya tulis ilmiah secara sepintas disebabkan oleh ketidakfahaman sistematika antara kaidah secara umum dan selingkung.

Oleh karena itu, diperlukan metode pembelajaran yang dapat membantu mahasiswa dalam karya tulis ilmiah. Pemilihan metode yang tepat sangat berpengaruh terhadap keberhasilan mahasiswa dalam karya tulis ilmiah. Adapun metode yang digunakan adalah discovery. Metode tersebut dapat mengoptimalkan kemampuan mahasiswa dalam menulis karya tulis ilmiah. Fakta yang diperoleh menunjukkan adanya kebutuhan akan metode pembelajaran yang tepat. 


\section{Daftar Pustaka}

Ahmad, Abu, dan Joko Tri Prasetyo. 2005. Strategi Belajar-Mengajar. Bandung: Pustaka Setia.

Burton, William. 1953. The Guidance of Learning Activity. New York: Appleton Century.

Djamarah, Syaiful Bahri. 1996. Strategi Belajar-Mengajar. Jakarta: Rineka Cipta.

Echol, John M., dan Hasan Sadili. 1996. Kamus Inggris-Indonesia. Jakarta: Gramedia.

Hamalik, Oemar. 1994. Pengembangan Kurikulum dan Pembelajaran; DasarDasar dan Strategi Pelaksanaannya di Perguruan Tinggi. Bandung: Trigenda Karya.

Http//www. DOAJ-write artikel journal. Diunduh 15 Maret 2021.

Ibrahim, R., dan Nana Syaodih. 2003. Perencanaan Pengajaran. Jakarta: Rineka Cipta.

Illahi, Muhammad Takdir. 2012. Pembelajaran Discovery Strategy dan Mental Vocanational Skill. Yogyakarta: Diva Press.

Siregar, Masarudin. 1985. Didaktik Metodik dan Kedudukan dalam Proses Belajar Mengajar. Yogyakarta: Subangsih.

validasi-karya-ilmiah\%20contoh\%20dari\%20dikti.pdf.

Elsevier. Co-Lab: research and development of an online learning environment for collaborative scientific discovery learning. Vol.21, Issue 4, July 2005, pages 671-688 (diunduh 21April 2021). 